\title{
Avoiding News Along the Coast
}

Along the coast of perpetual breezes I lay myself down. Half-light slowly all the way, like the lid of the earth twisted off.

Full contentment may be possible

for some. Full contentment rises

to meet me, close enough

to smack my face with its shoe, young enough it climbs inside my bed.

I want to live there on that other side of language when out leapt sound fully formed, mutual. Before the words took shape. Before meaning put the lid back on

all this. Before accent, back toward the pure infallible syllable could be honed. I don't want to point. I want to raise my hands. I want to cry out

with my hands raised, and run toward my mother or my father, it doesn't matter which, toward anyone who has inclined their life to mine, without my knowing it. Before they speak.

Before light was light, when the world was small as a question mark curling outward.

Before anyone could ask, "Can you hear me back there? Can you hear me now?" 